\title{
Effects of Various Antiseptics on Bacteremia Following Tooth Extraction
}

\author{
M. Kemal YAMALIK ${ }^{1}$, Sule YÜCETAS ${ }^{2}$ and Ufuk ABBASOǦLU ${ }^{3}$
}

(Received 19 June and accepted 20 September 1991)

Key words: antiseptics, bacteremia, local prophylaxis

\begin{abstract}
The effect of local irrigation of the gingival sulcus, which is considered an important source of bacteremia following dental procedures, with three different antiseptic solutions including hydrogen peroxide, chlorhexidine and povidone iodine, on the frequency of bacteremia after tooth extraction was determined, and the efficacies of the three antiseptics were compared. Although all the antiseptic solutions reduced the frequency of bacteremia to various degrees, povidone iodine was the most effective, and seemed to be the best choice since the decrease was statistically significant. Local administration of antiseptic solutions is therefore recommended as an adjuvant to systemic antibiotic prophylaxis.
\end{abstract}

\section{Introduction}

Although mostly occurring without any prominent symptom, transient bacteremia following dental procedures producing gingival bleeding is a common and well known phenomenon ${ }^{[1,2]}$. It is possible that bacteria enter the blood circulation from ruptured venous capillaries in the periodontal ligament and the base of the gingival sulcus by absorption and diffusion ${ }^{[3]}$. The bacteria found even in the healthy gingival sulcus are considered to be the most important source of bacte$\operatorname{remia}^{[4]}$.

Previous studies have reported that the frequency of bacteremia following tooth extraction varies between $12 \%$ and $90 \%{ }^{[3]}$. It has also been demonstrated that the incidence of bacteremia is apparently affected by various factors such as quality of oral hygiene, periodontal disease, periapical lesions, trauma and the performance duration of dental procedures ${ }^{[3,5-9]}$. The most commonly isolated bacterium in bacteremia is Streptococcus viridans. Numerous aerobic and anaerobic bacteria are also present ${ }^{[3,5,7]}$.

Although the existing bacteremia does not lead to any complication in

1 Research Assistant, Department of Oral and Maxillofacial Surgery, Faculty of Dentistry, University of Gazi, Ankara, TURKEY.

2 Professor, Department of Oral and Maxillofacial Surgery, Faculty of Dentistry, University of Gazi, Ankara, TURKEY.

3 Associate Professor, Department of Microbiology, Faculty of Pharmacy, University of Gazi, Ankara, TURKEY.

To whom all correspondence should be addressed: M. Kemal YAMALIK, Gazi UniversitesiDișhekimligi Fakültesi, Cerrahi Anabilim Dalı, 8. Cadde, Emek, Ankara, TURKEY. 
healthy individuals, serious problems may occur in patients from high-risk groups. In individuals with congenital or acquired heart disease or those fitted with a valvular prosthesis, circulating bacteria may reach the defective endocardium and cause bacterial endocarditis ${ }^{[2,6]}$. Such patients must be given antibiotic prophylaxis in order to prevent bacteremia. For this purpose, various agents and methods of prophylaxis have been recommended, but the results have not always been sufficient ${ }^{[2,3,10-12]}$. Local irrigation methods have also been recommended as an adjuvant to systemic antibiotic administration, and a combined mode of therapy, involving local and systemic treatment, has been suggested to be of great benefit ${ }^{[13]}$.

The aim of this study was to determine the effect on bacteremia of irrigation of the gingival sulcus with various antiseptic solutions and also to compare the effects of antiseptics that are widely used in clinical practice.

\section{Materials and Methods}

Eighty patients, 44 women and 36 men, with a mean age of $36.6 \mathrm{yr}$, were chosen from among systemically healthy individuals who had no history of drug administration during the previous week, who did not present any signs of acute oral infection, and for whom tooth extraction was scheduled.

The patients were divided into 4 groups, each containing 20 individuals. When grouping the patients, particular care was taken to ensure that the groups were similar with respect to age and sex. In order to eliminate the possible effects of certain dental pathologies on bacteremia, only molar teeth were extracted for endodontic, prosthetic and orthodontic reasons. Extracted teeth with alveolar bone loss and periapical problems were not included in the study. In each session, only one tooth was extracted and the time taken for extraction was less than $3 \mathrm{~min}$. All teeth were extracted using the same local anesthetic (Ultracain-DS-Hoechst).

In order to standardize the effect of the quality of oral hygiene on bacteremia, the oral hygiene index of GREENE AND VERMILLION ${ }^{[14]}$ was recorded in each patient, and only those patients with index scores of 1.3-3.0 (medium) were selected.

The patients were grouped as follows:

a) The first group was chosen as the control group, in which tooth extraction was performed without subsequent application of any solution.

b) In the second group, the gingival sulcus of the indicated tooth was irrigated before extraction with $10 \mathrm{ml}$ of $1 \%$ providone iodine, using a sterile plastic syringe with a blunt needle.

c) In the third group, similar irrigation of the gingival sulcus was performed using $10 \mathrm{ml}$ of $3 \%$ hydrogen peroxide.

d) In the last group, $10 \mathrm{ml}$ of $0.02 \%$ chlorhexidine was used as the antiseptic solution for gingival sulcus irrigation.

After local irrigation, the patients were instructed to rinse the mouth with the given antiseptic solution for $2 \mathrm{~min}$. Following local antiseptic application, the experimental teeth were extracted.

In patients from all of the four groups, $10 \mathrm{ml}$ of venous blood was obtained from the antecubital vein before and after tooth extraction. In order to eliminate the risk of contamination, the surface of the skin was cleaned with $70 \%$ isopropyl 
alcohol for $1 \mathrm{~min}$. The blood cultures were then incubated at $36^{\circ} \mathrm{C}$. Aliquots $(0.2$ $\mathrm{ml}$ ) were transferred to blood agar plates and incubated under aerobic and anaerobic conditions. Pure cultures of bacteria were prepared and identified using standard techniques.

The findings were then statistically evaluated ${ }^{[15]}$.

\section{Results}

The cultures of blood samples obtained before tooth extraction were negative in all of the 4 groups.

In the control group, 14 of the 20 post-extraction samples were positive under aerobic conditions, and the frequency of bacteremia in this group was $70 \%$.

In the second group, where the gingival sulcus had been irrigated with povidone iodine, 7 of the culture samples were positive and the bacteremia frequency was $35 \%$. The difference was statistically significant when compared to the control group $(\mathrm{p}<0.05)$.

In the third group, where hydrogen peroxide had been administered subgingivally, the frequency of bacteremia was $50 \%$, since 10 of the 20 culture samples were positive.

In the chlorhexidine group, the number of positive blood cultures was 8 and the frequency of bacteremia was $40 \%$. The difference between the control group and groups 3 and 4 was not statistically significant $(\mathrm{p}<0.05)$. (Fig. 1).

The types and ratios of microorganisms isolated from the positive blood

Table 1 Numbers of aerobic and anaerobic bacteria and the ratio to total culture number (tcn) in the control and experimental groups. The culture number of the identified bacteria and the ratio of positive blood samples (n) are shown.

\begin{tabular}{|c|c|c|c|c|c|c|c|c|}
\hline \multirow[b]{2}{*}{ Aerobic culture } & \multicolumn{2}{|c|}{$\begin{array}{l}\text { 1. group } \\
\text { control }\end{array}$} & \multicolumn{2}{|c|}{$\begin{array}{c}\text { 2. group } \\
\text { Povidone Iodine }\end{array}$} & \multicolumn{2}{|c|}{$\begin{array}{l}\text { 3. group } \\
\text { Hydrogen Per. }\end{array}$} & \multicolumn{2}{|c|}{$\begin{array}{l}\text { 4. group } \\
\text { Chlorhexidine } \\
n: 8 \text { tcn }: 12\end{array}$} \\
\hline & 16 (55.2\%) & & $\begin{array}{l}6 \\
(66.6 \%)\end{array}$ & & $\begin{array}{l}8 \\
(72.7 \%)\end{array}$ & & $\begin{array}{l}8 \\
(66.6 \%)\end{array}$ & \\
\hline S. viridans & & $\begin{array}{l}7 \\
(50 \%)\end{array}$ & & $\begin{array}{l}3 \\
(42.8 \%)\end{array}$ & & $\begin{array}{l}2 \\
(10 \%)\end{array}$ & & $\begin{array}{l}4 \\
(50 \%)\end{array}$ \\
\hline Micrococcus & & $(7.1 \%)$ & & - & & - & & - \\
\hline Diphtherioid & & 6 & & $\begin{array}{l}3 \\
(42.8 \%)\end{array}$ & & - & & $\begin{array}{l}4 \\
(50 \%)\end{array}$ \\
\hline Neisseria & & 2 & & - & & $\begin{array}{l}6 \\
(60 \%)\end{array}$ & & - \\
\hline Anaerobic culture & $\begin{array}{l}13 \\
(44.8 \%)\end{array}$ & & $\begin{array}{l}3 \\
(33.3 \%)\end{array}$ & & $\begin{array}{l}3 \\
(27.3 \%)\end{array}$ & & $\begin{array}{l}4 \\
(33.3 \%)\end{array}$ & \\
\hline Actinomyces & & $\begin{array}{l}7 \\
(50 \%)\end{array}$ & & - & & $\begin{array}{l}3 \\
(30 \%)\end{array}$ & & - \\
\hline Lactobacillus & & $\begin{array}{l}3 \\
(21.4 \%)\end{array}$ & & $\begin{array}{l}3 \\
(42.8 \%)\end{array}$ & & - & & $\begin{array}{l}2 \\
(25 \%) \\
\end{array}$ \\
\hline Veillonella & & $17.1 \%)$ & & - & & - & & $\begin{array}{l}2 \\
(25 \%)\end{array}$ \\
\hline Spirillum & & 2 & & - & & - & & - \\
\hline Total culture & $\begin{array}{l}29 \\
(100 \%)\end{array}$ & & $\begin{array}{l}9 \\
(100 \%)\end{array}$ & & $\begin{array}{l}11 \\
(100 \%)\end{array}$ & & $\begin{array}{l}12 \\
(100 \%)\end{array}$ & \\
\hline
\end{tabular}




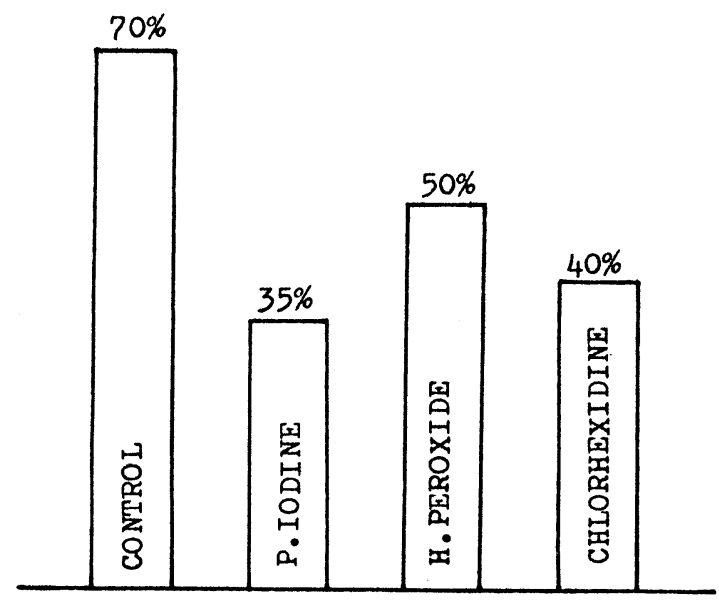

Fig. 1 The incidence of bacteremia in the control and experimental groups

samples and also the number of aerobic, anaerobic and total microorganism cultures are given in Table 1.

\section{Discussion}

The principal of prophylaxis for bacterial endocarditis is to minimize the number of bacteria invading the blood circulation. For this purpose, local irrigation of the gingival sulcus, considered to be a major source of bacteremia, with antibacterial agents can be beneficial. Although the preventive effect of local irrigation has been demonstrated in previous studies, the concept is still somewhat controversial.

There are reports which suggest that irrigation of the gingival sulcus of teeth with antiseptic solutions before extraction, could decrease the frequency of bacteremia by half ${ }^{[13,16]}$. On the other hand, antiseptic solutions have also been found to be ineffective for prevention of becteremia ${ }^{[3]}$. These conflicting data indicate that further studies are necessary. Furthermore, comparison of the effects of various antiseptic solutions might reveal new concepts and data.

In studies of bacteremia, to make the results more reliable, standardization of the factors which can influence bacteremia is essential. Poor oral hygiene and the presence of periodontal disease and/or periapical infections are considered to be potential sources of bacteremia ${ }^{[5-7]}$. Also the trauma associated with the duration and type of manipulation during tooth extraction has been shown to increase the frequency of bacteremia ${ }^{[3,8,9]}$. Therefore, in the present study, the factors known to affect bacteremia were standardized. In each session, only one molar tooth was extracted and the extraction was completed within $3 \mathrm{~min}$. Also, special care was taken to ensure that none of the extracted teeth had signs of periodontal and/or periapical infection. In addition, the mean oral hygiene scores were similar among the patients. Furthermore, in order to eliminate the effect of mechanical cleaning, sterile saline irrigation was not used in the control group. The positive results 
obtained following the administration of antiseptics are attributable to both their antibacterial effect ${ }^{[17]}$ and mechanical elimination of existing bacteria ${ }^{[18]}$.

Since the results for the different antiseptic solutions used in the present study showed significant variances, the antibacterial effect of antiseptic solutions was considered to be important.

The blood samples obtained before tooth extraction were completely negative for bacteria. This confirms that with careful asepsia, skin contamination can be prevented. The bacteria isolated from the pre-extraction samples were Staphylococcus species, and this was interpreted to indicate insufficient disinfection and contamination of the cultures by remaining Staphylococcus ${ }^{[3]}$.

Povidone iodine and chlorhexidine are widely used in clinical practice because of their strong antibacterial effects. Although its antiseptic effect is poor, hydrogen peroxide is frequently used for antisepsis because of the mechanical cleaning effect it exerts during effervescence and its effect on anaerobic bacteria $^{[19-21]}$

$\mathrm{N}_{\text {ASIF }}{ }^{[16]}$ has demonstrated a $50 \%$ decrease in bacteremia following gingival irrigation with hydrogen peroxide, and a similar action has been suggested for povidone iodine ${ }^{[13]}$. Several studies have also revealed a significant decrease in postoperative bacteremia through the use of povidone iodine ${ }^{[22]}$.

BENDER et al. ${ }^{[23]}$ have shown that with chlorhexidine application, the number of bacteria in the oral cavity is significantly reduced. MACFARLANE et al. ${ }^{[17]}$ have reported that post-extraction bacteremia is best prevented by chlorhexidine administration.

While the frequency of bacteremia in the control group was $70 \%$, the frequency in the povidone iodine group was $35 \%$, the difference between the groups being statistically significant. Chlorhexidine decreased the frequency to $40 \%$ and hydrogen peroxide to $50 \%$, but the results were not significant.

The findings of the present study are in accord with SCOPP AND ORviETo ${ }^{[13]}$ and BRENMANN AND RANDELL ${ }^{[22]}$, who have reported a significant reduction of postoperative bacteremia after povidone iodine irrigation. On the other hand, our findings also confirm that systemic prophylaxis cannot be replaced by local prophylaxis measures.

SCOPP AND ORVIETO ${ }^{[13]}$ reported a 50\% decrease in bacteremia with antiseptic application. They have also demonstrated that prophylaxis with systemic penicillin administration had a similar effect, and that the combined systemic and local prophylaxis method decreased the frequency of bacteremia from $87 \%$ to $5 \%$.

Most authors agree that $S$. viridans is the most frequent type of bacterium isolated after dental procedures ${ }^{[2,3,6,10,24]}$. The present findings support the previous ones, but also suggest that Neisseria, diphtheroid and Lactobacillus species could play a role in bacteremia.

Antiseptics, when administered alone, cannot completely eliminate bacteremia, but do exert a preventive effect. Therefore it is suggested that in patients from high-risk groups before dental procedures which cause bleeding, irrigation of the gingival sulcus with antiseptics, preferably povidone iodine, can be used as an adjuvant to systemic prophylaxis. 


\section{References}

[1] Rahn, R., Shah, P. M., Schaefer, V., Muggenthaler, F., Frenkel, G. and Knothe, H.: Orale Endokarditis Prophylaxe bei Zahnaerztlich-Chirurgischen Eingriffen, Schweiz. Monatsschr. Zahnmed., 98, 478-481, 1988

[2] Mombelli, G.: Endokarditis-Prophylaxe und Therapie, Schweiz. Med. Wschr., 114, 73-77, 1984

[3] Jokinen, M. A.: Bacteremia following dental extraction and its prophylaxis, Suom. Hammaslaak Toim, 66, 69-100, 1970

[4] Jones, J. C., Cutcher, J. L., Goldberg, J. R. and Lilly, G. E.: Control of Bacteremia associated with extraction of teeth, Oral Surg., 30, 454-459, 1970

[5] Nolte, W. A.: Oral Microbiology with Basic Microbiology and Immunology, 4th Ed., 670-685, The C. V. Mosby Co., St. Louis, U. S. A., 1982

[6] Committee on Rheumatic Fever and Infective Endocarditis of The American Heart Association: Prevention of Bacterial Endocarditis, J.A.D.A., 110, 98-100, 1985

[7] Rahn, R., Shah, P. M., Schaefer, V., Frenkel, G. and Halbherr, K.: Bakteriaemie nach Zahnentfernung-Einfluss Verschiedener Faktoren, Z.W.R., 95, 822-826, 1986

[8] King, R. C., Crawford, J. J. and Small, E. W.: Bacteremia following intraoral suture removal, Oral Surg., 61, 23-28, 1988

[9] Rahn, R., Shah, P. M., Schaefer, V., Frenkel, G. and Halbherr, K.: Bakteriaemie nach Zahnentfernung-Einfluss von Art and Dauer des Eingriffes, Z.W.R., 95, 1056-1063, 1986

[10] Malinverli, R., Francioli, P., Gerber, A., Glauser, M. P., Hirschel, B., Lüthy, R., Mombelli, G., Regamey, C., Schadd, U. B., Schedelin, J., Stalder, H. and Zimmerli, W.: Prophylaxe der Bakteriellen Endokarditis, Schweiz. Med. Wschr., 114, 1246-1252, 1984

[11] Meier, B., Lüthy, R. and Siegenthaler, W.: Endokarditis-Prophylaxe mit Amoxycillin, Clindamycin oder Erytromycin, Schweiz. Med. Wschr., 114, 1252-1256, 1984

[12] Durack, D. T., Kaplan, E. L. and Bisno, A. L.: Apparent failures of endocarditis prophylaxis, J.A.M.A., 250, 2318-2322, 1983

[13] Scopp, I. W. and Orvieto, L. D.: Gingival degerming by povidone-iodine irrigation, bacteremia reduction in extraction procedures, J.A.D.A., 83, 1294-1296, 1971

[14] Greene, J. C. and Vermillion, J. R.: Oral hygiene index: A method for classifying oral hygiene status, J.A.D.A., 61, 172-179, 1960

[15] Sokal, R. R. and Rohlf, F. J.: Biometry, 343-365, 494-548, W. H. Freeman and Co., San Francisco, U. S. A., 1969

[16] Nasif, A. S.: The incidence of post-extraction bacteremia after irrigation of the gingival sulcus with hydrogen peroxide solution, Egypt. Dent. J., 23, 51-55, 1977

[17] MacFarlane, T. W., Ferguson, M. M. and Mulgrew, C. J.: Post-extraction bacteremia: Role of antiseptics and antibiotics, Br. Dent. J., 156, 179-181, 1984

[18] Sweet, J. B. and MA Cynski, A. A.: Effect of antimicrobial mouth rinses on the incidence of localized alveolitis and infection following mandibular third molar surgery, Oral Surg., 59, 24-26, 1985

[19] Meyers, F. H., Jawetz, E. and Goldfien, A.: Lehrbuch der Pharmakologie, 628-633, Springer Verlag, Berlin, B. R. D., 1975

[20] Estler, C. J.: Pharmakologie für Zahnmediziner, 3. Auflage, 199-215, Schattauer, Stuttgart, B.R.D., 1989

[21] Wenstrom, J. and Lindhe, J.: Effect of hydrogen peroxide on developing plaque and gingivitis in man, J. Clin. Periodontol., 6, 115-130, 1979

[22] Brenman, H. S. and Randall, E. R.: Local degerming with povidone-iodine. 11. Prior to gingivectomy, J. Periodontol., 45, 870-872, 1974

[23] Bender, I. B., Naidorf, I. J. and Garvey, G. J.: Bacterial endocarditis: a consideration for physician and dentist, J.A.D.A., 415-420, 1984

[24] Hellenbrecht, D.: Pharmakologie für Zahnmediziner, 213-217, Schwer, Stuttgart, B.R.D., 1988 